\title{
Temporal influence on the functional traits of testate amoebae in a floodplain lake
}

\author{
Leilane Talita Fatoreto Schwind*, Rodrigo Leite Arrieira, Tatiane Mantovano, Claudia Costa \\ Bonecker and Fábio Amodêo Lansac-Tôha
}

State University of Maringa, Nupélia, Colombo Avenue, 5790 Maringa, PR, Brazil.

* Corresponding author: leschwind@gmail.com

Received: $14 / 12 / 2015$

Accepted: 08/06/2016

\begin{abstract}
Temporal influence on the functional traits of testate amoebae in a floodplain lake

Comprehending functional traits is increasingly recognized as an important element in the investigation of community assembly. We hypothesized that the homogenization effect of floods will lead to trait convergence in flooding periods, while environmental isolation will lead to trait divergence in drought periods. Sampling was carried out during two hydrological periods between 2002 and 2011 in a floodplain lake. The traits considered were taxonomical grouping, origin of the shell material, and presence of gas vacuoles. A functional dispersion index was calculated to detect trait convergence or divergence related to the hydrological periods over time. A redundancy analysis was carried out to investigate how the functional traits of the testate amoebae were linked to environmental variables during the different hydrological periods. We recorded seventy-nine taxa belonging to eight families. The functional index of testate amoebae indicated a predominant pattern of trait convergence in flooding and trait divergence in drought. Our results indicated that hydrological periods influence the functional traits of testate amoebae (indicating those typical of drought and flooding periods), which are strongly influenced by environmental variables related to food resources, especially chlorophyll $a$.
\end{abstract}

Key words: Protozoa, plankton, functional diversity, hydrological periods.

\section{RESUMO}

Influência temporal sobre os traços funcionais de amebas testáceas em uma lagoa de uma planície de inundação neotropical

A compreensão sobre a distribuição dos traços funcionais das espécies tem sido considerada como um elemento importante na investigação da estrutura das comunidades. Avaliou-se a hipótese de que o efeito da homogeneização das inundações promoverá a convergência de traços funcionais no período de cheia enquanto que o isolamento ambiental promoverá a divergência de traços funcionais no período de seca. As coletas foram realizadas em dois períodos hidrológicos, entre 2002 e 2011, em uma lagoa de uma planície de inundação. Os traços funcionais utilizados foram: classificação taxonômica, constituição da carapaça e presença ou ausência de vacúolo gasoso. Um índice de dispersão funcional foi calculado para indicar a convergência ou divergência de traços funcionais relacionadas com os períodos hidrológicos, ao longo do tempo. A análise de redundância foi realizada para investigar como os traços funcionais estavam sendo relacionados com as variáveis ambientais, durante os períodos hidrológicos. Foram registrados 79 táxons pertencentes a oito famílias. O índice funcional indicou a predominância de convergência de traços funcionais na cheia e divergência de traços funcionais na seca. Os resultados indicaram que os períodos hidrológicos influenciaram os traços funcionais das amebas testáceas, que são fortemente influenciadas pelas variáveis ambientais relacionadas com os recursos alimentares, especialmente a clorofila-a.

Palavras-chave: Protozoa, plâncton, diversidade funcional, períodos hidrológicos. 


\section{INTRODUCTION}

Comprehending the functional traits that drive community organization is increasingly recognized as an important element in the investigation of community assembly (McGill et al., 2006). Species characteristics are investigated through any measurable morphological, physiological, or life-history characteristic linked to individual fitness (Violle et al., 2007). Thus, functional traits provide insight into how species respond to ecosystem processes over time and may reveal assembly patterns to help predict community structure and ecosystem functioning (Petchey \& Gaston, 2006; Vogt et al., 2010).

Community assembly apparently involves two main trends: (1) species in a community can be similar in their ecological requirements, leading to trait convergence; or (2) species coexistence may be restricted by their trait similarity, which may lead to trait divergence (Pillar et al., 2009). Using a functional diversity index can be a good approach to investigate which ecological process is predominant in a community by calculating community-observed measures of such processess and comparing them with random expectations (Cavender-Bares et al., 2006; Luck et al., 2013).

The hydrological regime is known as a major structuring factor for temporal dynamics and ecological processes in floodplains (Junk et al., 1989). Thus, this temporal factor can influence the functional traits of species as a consequence (Mendez et al., 2012). Aquatic communities respond differently to temporal variation in each hydrological period. Drought periods lead to environmental isolation and to specific physical and chemical characteristics of each environment, distinguishing environments with a decrease in the water level, which may cause divergence in the functional traits of species. Flooding periods show an increase in most environmental variable concentrations due to the homogenization effect of floods, which equalizes the environmental conditions of the subsystems and causes the convergence of functional traits of the species (Thomaz et al., 2007).

Testate amoebae are organisms that play important roles in structuring aquatic ecosystems and have interesting characteristics and ecological advantages for scientific investigations (Schwind et al., 2016). They have shells of diffe-

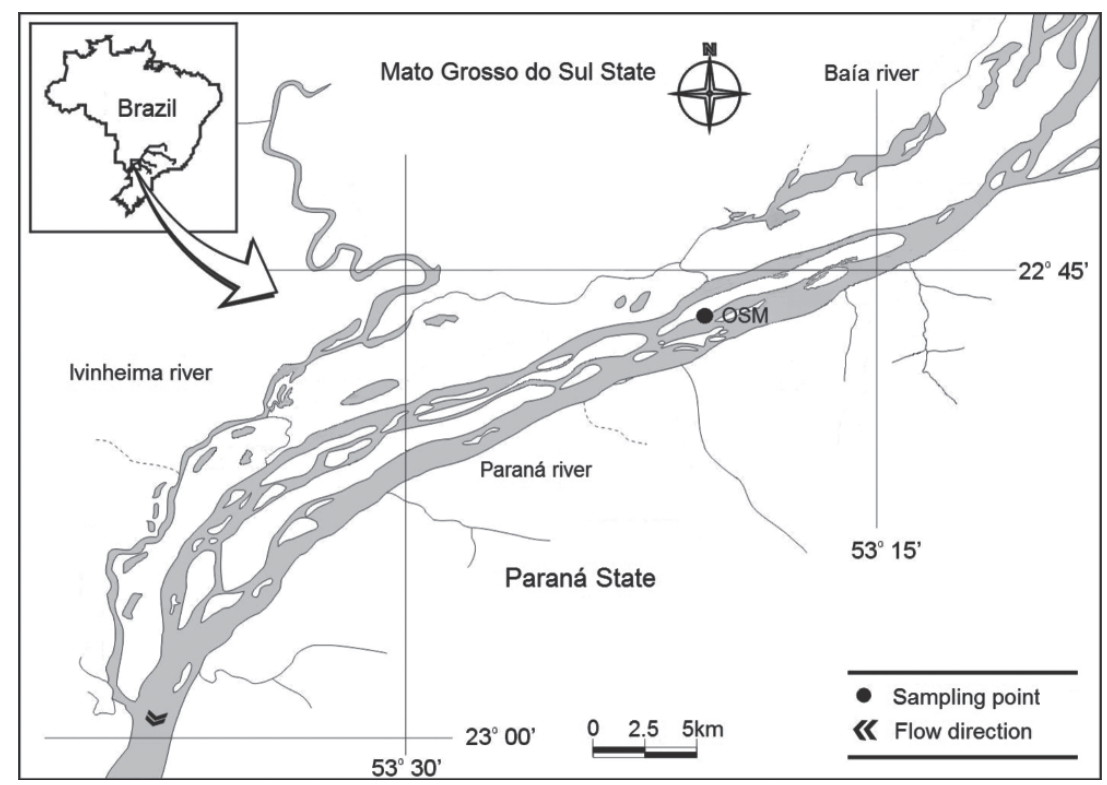

Figure 1. Sampling location of the environment in the upper Paraná River floodplain (OSM = Osmar Lake). Ponto de amostragem na planície de inundação do alto rio Paraná (OSM = lagoa Osmar). 
rent compositions, shapes, and sizes (Bonnet, 1975). These morphological characteristics are believed to represent adaptations to environmental conditions, especially in aquatic environments that are constantly affected by floods and changing environmental conditions (Alves et al., 2008).

The functional traits of testate amoeba communities are poorly understood. Attempts to explain testate amoeba traits have been mainly limited to studying minute soil taxa (Fournier et al., 2012). Thus, the present study investigated the influence of hydrological periods on the functional traits of testate amoebae in a floodplain lake. We hypothesized that the homogenization effect of floods will lead to trait convergence during periods of flooding, while environmental isolation will lead to trait divergence during drought. Moreover, the environmental variables will differentially influence the functional traits of testate amoebae in both hydrological periods.

\section{MATERIALS AND METHODS}

\section{Study Area}

This study was performed at Osmar Lake, a water body occupying the upper Paraná River floodplain that is part of the Environmental Protection Area of the Paraná River of the Várzea Islands, Brazil $\left(22^{\circ} 40^{\prime}-22^{\circ} 50^{\prime} \mathrm{S}\right.$ and $53^{\circ} 10^{\prime}$ $53^{\circ} 40^{\prime} \mathrm{W}$ ) (Fig. 1).

Floodplain lakes are greatly affected by the hydrological regime, showing clear temporal differences between flooding and drought (Bonecker et al., 2009). Osmar Lake is an isolated lake in the Paraná River. It is not connected to the main river channel except during major floods. It is a quite shallow lake with a minimum depth of 0.6 metres during drought and a maximum depth of $4.5 \mathrm{~m}$ during flooding (Roberto et al., 2009).

\section{Sampling design}

Amoeba samples were taken during flooding (February) and drought (September) from 2002 to 2011 on the subsurface of the pelagic zone. Six hundred litres of water per sample were filt- ered through a plankton net $(68 \mu \mathrm{m})$ at a central point of the lake using a pump motor. This material was fixed with a $4 \%$ formaldehyde solution buffered with calcium carbonate.

The following variables were also measured: water temperature $\left({ }^{\circ} \mathrm{C}\right)$, concentration of dissolved oxygen $(\mathrm{mg} / \mathrm{L})$ (portable digital oximeterYSI 550A), water transparency and depth (Secchi disk), turbidity (NTU), alkalinity (mEq/L), total nitrogen $(\mu \mathrm{g} / \mathrm{L})$, nitrate $(\mu \mathrm{g} / \mathrm{L})$, ammonia $(\mu \mathrm{g} / \mathrm{L})$, total phosphorous $(\mu \mathrm{g} / \mathrm{L})$, phosphate $(\mu \mathrm{g} / \mathrm{L}), \mathrm{pH}$ (portable digital $\mathrm{pH}$ metre-Digimed DM-2) and chlorophyll $a(\mu \mathrm{g} / \mathrm{L})$. The samples were analysed in the laboratory according to Golterman et al. (1978) and Mackereth et al. (1978).

The testate amoeba abundance was determined by counting the amoebae using a Sedgewick-Rafter chamber under an optical microscope. This counting was performed in sets of three sequential sub-samples obtained by a Hensen-Stempel pipette, and at least 50 individuals were counted per sample, evaluating $7.5 \mathrm{~mL}$ from each sample in total. The samples were fully quantified when the minimum number of individuals per sample was not reached (Bottrell et al., 1976).

\section{Functional Traits}

The functional traits were calculated by summing the abundance of organisms according to each functional trait and were expressed as individuals per $\mathrm{m}^{3}$. Three functional traits were selected: taxonomic classification (Arcellinida or Euglyphida), shell constitution (agglutinated, proteinaceous, or siliceous shell) and gas vacuole (presence or absence) (See Table S1, available at www.limnetica.com).

The taxonomic classification can be determined by the pseudopod morphology: filose or lobose. These correspond to two of the three phylogenetic groups distinguished in testate amoebae (Meisterfeld, 2002; Nikolaev et al., 2005): Euglyphida have filose pseudopods, are mainly smaller, bacteria-feeding taxa and are generally considered r-strategists. Arcellinida includes both smaller and larger taxa, and its members have lobose pseudopods and are considered 
K-strategists. The shell constitution in testate amoebae differs according to the composition: a proteinaceous, calcareous, or siliceous shell that is secreted by the organism or a shell composed of medium particles such as mineral particles and diatom frustules that are combined into a cement matrix by the organism (agglutinated shell) (Beyens \& Meisterfeld, 2001). The differences in test constitution are believed to represent adaptations of these organisms to changes in the environment (Fournier et al., 2012; Arrieira et al., 2015a). Gas vacuoles are structures used by testate amoebae to move from the bottom to the surface by floating (Ogden, 1991). Shell compression minimizes the resistance to water and floatation (Velho et al., 2003). Both gas vacuoles and shell compression are considered adaptations that enable organisms to remain active longer in the water column. However, these adaptations could influence the planktonic communities because the water column have greater availability of food resources, such as phytoplankton (Auer et al., 2004).

\section{Data analysis}

The functional dispersion index (FDis) was calculated to detect trait convergence or divergence related to the hydrological periods over time. FDis was proposed by Laliberté \& Legendre (2010) to provide a measure of multivariate dispersion that estimates the dispersion of species in functional space. According to the authors, FDis is the mean distance in multidimensional trait space of individual species to the centroid of all species. It can account for species abundances by shifting the position of the centroid towards the more abundant species and weighting the distances of individual species by their relative abundances. This index represents different aspects of functional diversity and, therefore, provides complementary pieces of information that a single index could not impart. FDis was computed using the "FD" package (Laliberté \& Legendre, 2010) of the R free software, version 3.0.1 (R Core Team, 2013).

To assess whether trait convergence or divergence dominates in different hydrological periods, we conducted the following analysis: a permutation test was computed such that rows were permuted in the species per trait matrix to randomly attribute trait values to species, preserving species abundance and richness at the same time. This was repeated 999 times, allowing us to generate a probability distribution (FDis_sim) that was used to calculate $p$-values. The three possible outcomes of this test are 1) FDis $<5$ th percentile of FDis_sim: convergence of traits; 2) FDis > 95th percentile of FDis_sim: divergence of traits; 3) 5th percentile of FDis_sim $<$ FDis $<95$ th percentile of FDis_sim: neither convergence nor divergence of traits. Thus, the community does not follow any particular rule but is stochastic. We assume that the homogenization effect of floods

Table 1. Results of the observed functional index (FDis) and probability distribution (FDis_sim) generated for the testate amoeba communities during flooding. Measures in bold indicate trait convergence. Resultados do índice funcional observado (FDis) e a probabilidade de distribuição (FDis_sim) gerada para a comunidade de amebas testáceas no período de cheia. Medidas em negrito indicam a convergência dos traços funcionais.

\begin{tabular}{|c|c|c|c|c|}
\hline Sampling years & $\begin{array}{l}\text { 5th percentile of } \\
\text { FDis_sim }\end{array}$ & $\begin{array}{l}\text { 95th percentile of } \\
\text { FDis_sim }\end{array}$ & FDis & $p$-values \\
\hline 2002 & $0.187-0.187$ & $0.291-0.291$ & 0.273 & $0.05<p<0.95$ \\
\hline 2003 & 0.067-0.77 & $0.286-0.286$ & 0.067 & $p<0.05$ \\
\hline 2004 & $0.120-0.120$ & $0.288-0.288$ & 0.120 & $p<0.05$ \\
\hline 2005 & 0.058-0.058 & $0.277-0.277$ & 0.058 & $p<0.05$ \\
\hline 2006 & $0.075-0.140$ & $0.308-0.308$ & 0.076 & $p<0.05$ \\
\hline 2007 & $0.221-0.222$ & $0.297-0.297$ & 0.221 & $p<0.05$ \\
\hline 2008 & $0.050-0.060$ & $0.288-0.289$ & 0.055 & $p<0.05$ \\
\hline 2009 & $0.200-0.201$ & $0.338-0.353$ & 0.201 & $p<0.05$ \\
\hline 2010 & $0.057-0.057$ & $0.291-0.292$ & 0.154 & $0.05<p<0.95$ \\
\hline 2011 & 0.115-0.116 & $0.291-0.292$ & 0.116 & $p<0.05$ \\
\hline
\end{tabular}


will lead to the convergence of traits in flooding (case 1), while environmental isolation will lead to the divergence of traits in drought (case 2). In an intermediate situation, we would observe neither the convergence nor divergence of traits (case 3 ).

We also carried out a redundancy analysis (RDA) (Legendre \& Legendre, 1998) to investigate how the functional traits of the testate amoebae were linked to the environmental variables during the different hydrological periods. The RDA results were based on the percentage of variation explained by the model ( $\mathrm{R}^{2}$ adjusted). We applied a log transformation to the functional trait values to reduce the effect of rare species and subsequently processed these data according to the Hellinger transformation (Legendre \& Gallagher, 2001). The RDA tests also included the "vif.cca" function in the R program (variance inflation factors -VIFs) to detect multicollinear variables, and those with a VIF value higher than ten were removed (Borcard et al., 2011). We also performed a Monte Carlo permutation test (999 randomizations) (Borcard et al., 1992) to investigate if the relationships between the environmental parameters and the RDA axes were statistically significant $(p<0.05)$. The RDA analyses were conducted using the "vegan" package (Oksanen et al., 2011) of the R free software, version 3.0.1 (R Core Team, 2013).

\section{RESULTS}

The species composition of the testate amoebae included seventy-nine taxa belonging to eight families; Difflugiidae showed the highest number of species (36 taxa), followed by Arcellidae (19 taxa), Centropyxidae (10 taxa), Lesquereusiidae (10 taxa), Trigonopyxidae (one taxon), Euglyphidae (one taxon), Phryganellidae (one taxon), and Plagiopyxidae (one taxon) (Table S1).

Significant differences between hydrological periods were found for the testate amoeba communities when compared using the observed functional index (FDis). In addition, the FDis measures were different in the hydrological periods according to the probability distribution (FDis_sim) generated for the testate amoeba

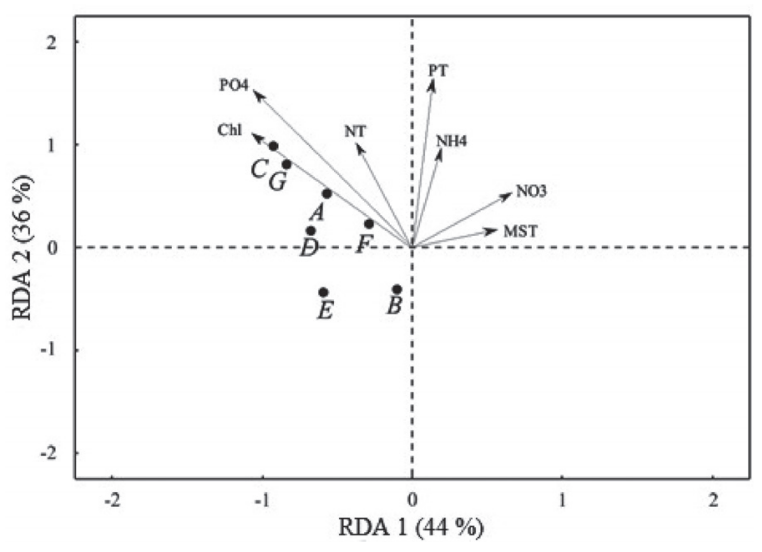

Figure 2. Relationships between the environmental variables and the functional traits of the testate amoebae during flooding. Functional traits: $\mathrm{A}=$ Arcellinida; $\mathrm{B}=$ Euglyphida; $\mathrm{C}=$ agglutinated; $\mathrm{D}=$ proteinaceous $; \mathrm{E}=$ siliceous; $\mathrm{F}=$ presence of gas vacuoles; $\mathrm{G}=$ absence of gas vacuoles. Limnological variables: MST $=$ total suspended matter; $\mathrm{NT}=$ total nitrogen; $\mathrm{NO}_{3}=$ nitrate; $\mathrm{NH}_{4}=$ ammonia; $\mathrm{PT}=$ total phosphorous; $\mathrm{PO}_{4}=$ phosphate $\mathrm{Chl}=$ chlorophyll $a$. Water temperature, concentration of dissolved oxygen, water transparency, depth, turbidity, alkalinity and $\mathrm{pH}$ showed a high VIF and were excluded from the analysis. Relação entre as variáveis ambientais e as características funcionais das amebas testáceas no período de cheia. Traços funcionais: $A=$ Arcellinida; $B=$ Euglyphida $; C=$ aglutinada; $D=$ proteica $; E=$ silicosa $; F=$ presença de vacúolo gasoso; $G=$ ausência de vacúolo gasoso. Variáveis limnológicas: $M S T$ = material total em suspensão; $N T=$ nitrogênio total; $\mathrm{NO}_{3}=$ nitrato; $\mathrm{NH}_{4}=$ amônia $; \mathrm{PT}=$ fósforo total; $\mathrm{PO}_{4}=$ fosfato $; \mathrm{Chl}$ = clorofila-a. Temperatura da água, concentração de oxigênio dissolvido, transparência da água, turbidez, alcalinidade e $\mathrm{pH}$ mostraram elevado valor de VIF e foram excluídos da análise.

communities. During flooding, most of the FDis measures were found in between the lowest measures of FDis_sim (Table 1).

In this way, the functional traits of the testate amoebae showed a predominant trait convergence in this hydrological period. In contrast, most of the FDis measures were found to occur between the highest measures of FDis_sim during drought (Table 2), indicating trait divergence in the testate amoeba communities.

The first two RDA axes explained $80 \%$ of the relationship between the functional traits and the environmental variables during flooding, and $69.6 \%$ of this relationship was observed in drought (Figs. 2; 3). In addition, the results from the permutation tests revealed a statistically significant explanation attributed to $\operatorname{RDA}(p<0.05)$ in both hydrological periods. 


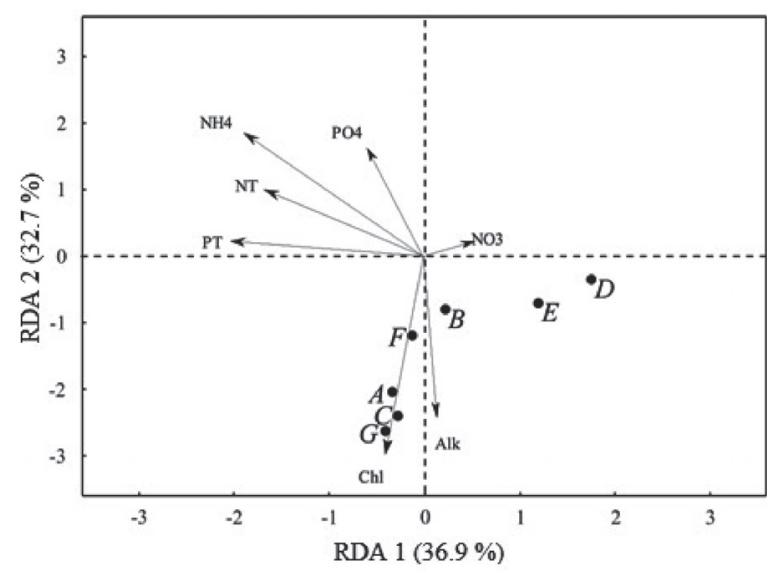

Figure 3. Relationships between the environmental variables and the functional traits of the testate amoebae during drought. Functional traits: $\mathrm{A}=$ Arcellinida $; \mathrm{B}=$ Euglyphida $; \mathrm{C}=$ agglutinated $; \mathrm{D}=$ proteinaceous $; \mathrm{E}=$ siliceous $; \mathrm{F}=$ presence of gas vacuoles; $\mathrm{G}=$ absence of gas vacuoles. Limnological variables: Alk = alkalinity; $\mathrm{NT}=$ total nitrogen; $\mathrm{NO}_{3}=$ nitrate $; \mathrm{NH}_{4}=\mathrm{am}-$ monia; $\mathrm{PT}=$ total phosphorous; $\mathrm{PO}_{4}=$ phosphate $; \mathrm{Chl}=$ chlorophyll $a$. Water temperature, concentration of dissolved oxygen, water transparency, depth, turbidity, total suspended matter and $\mathrm{pH}$ showed a high VIF and were excluded from the analysis. Relação entre as variáveis ambientais e as características funcionais das amebas testáceas no período de seca. Traços funcionais: $A=$ Arcellinida $; B=$ Euglyphida $; C=$ aglutinada $; D$ = proteica $; E=$ silicosa $; F=$ presença de vacúolo gasoso; $G$ = ausência de vacúolo gasoso. Variáveis limnológicas: Alk = alcalinidade; $N T=$ nitrogênio total $; \mathrm{NO}_{3}=$ nitrato; $\mathrm{NH}_{4}=$ amônia; $P T=$ fósforo total $; \mathrm{PO}_{4}=$ fosfato $;$ Chl = clorofilaa. Temperatura da água, concentração de oxigênio dissolvido, transparência da água, turbidez, material total em suspensão e pH mostraram elevado valor de VIF e foram excluídos da análise.

The functional traits of testate amoebae Arcellinida (A), agglutinated (C), presence of gas vacuole $(\mathrm{F})$, and absence of gas vacuole $(\mathrm{G})$ were positively correlated to chlorophyll $a$ in both hydrological periods. During flooding, the total phosphorus and ammonia showed a negative correlation with Euglyphida (B), and nitrate showed a negative correlation with siliceous shell (E) (Fig. 2). During drought, the RDA showed a negative correlation between total phosphorus and proteinaceous shell (D), a negative correlation among total nitrogen, ammonia, and siliceous shell (E), as well as phosphate and Euglyphida (B) (Fig. 3).

\section{DISCUSSION}

We observed that the Difflugiidae and Arcellidae had the highest species richness in this study, as previously shown in other studies in floodplain lakes (Lansac-Tôha et al., 2014; Arrieira et al., 2015b; Schwind et al., 2016). In general, the higher the species richness in a community, the more the functional implications between traits and environments can be clarified (Weiher \& Keddy, 1999).

Our results indicated that the functional traits of testate amoebae differed in the two hydrological periods. Flood pulses and environmental isolation have direct influences on species assembly during flooding and drought, respectively. These processes result in different temporal distributions of aquatic communities in floodplains (Bo-

Table 2. Results of the observed functional index (FDis) and probability distribution (FDis_sim) generated for the testate amoeba communities during drought. Measures in bold indicate trait divergence. Resultados do índice funcional observado (FDis) e a probabilidade de distribuição (FDis_sim) gerada para a comunidade de amebas testáceas no período de seca. Medidas em negrito indicam a divergência dos traços funcionais.

\begin{tabular}{ccccc}
\hline \multirow{2}{*}{ Sampling years } & $\begin{array}{c}\text { 5th percentile of } \\
\text { FDis_sim }\end{array}$ & $\begin{array}{c}\text { 95th percentile of } \\
\text { FDis_sim }\end{array}$ & \multicolumn{2}{l}{ FDis } \\
\hline 2002 & $0.151-0.152$ & $\mathbf{0 . 2 7 0 - 0 . 2 8 0}$ & $\mathbf{0 . 2 7 1}$ & $\boldsymbol{p}>\mathbf{0 . 9 5}$ \\
2003 & $0.182-0.192$ & $\mathbf{0 . 2 7 4 - 0 . 2 8 3}$ & $\mathbf{0 . 2 7 5}$ & $\boldsymbol{p}>\mathbf{0 . 9 5}$ \\
2004 & $0.010-0.032$ & $0.259-0.259$ & 0.046 & $0.05<p<0.95$ \\
2005 & $0.077-0.078$ & $0.226-0.227$ & 0.101 & $0.05<p<0.95$ \\
2006 & $0.001-0.002$ & $0.290-0.290$ & 0.001 & $p<0.05$ \\
2007 & $0.083-0.083$ & $0.291-0.291$ & 0.083 & $p<0.05$ \\
2008 & $0.014-0.014$ & $\mathbf{0 . 2 5 7 - 0 . 2 5 8}$ & $\mathbf{0 . 2 5 7}$ & $\boldsymbol{p}>\mathbf{0 . 9 5}$ \\
2009 & $0.144-0.145$ & $\mathbf{0 . 2 6 9 - 0 . 2 8 6}$ & $\mathbf{0 . 2 6 9}$ & $\boldsymbol{p}>\mathbf{0 . 9 5}$ \\
2010 & $0.001-0.001$ & $\mathbf{0 . 0 0 2 - 0 . 0 0 3}$ & $\mathbf{0 . 0 0 3}$ & $\boldsymbol{p}>\mathbf{0 . 9 5}$ \\
2011 & $0.036-0.043$ & $\mathbf{0 . 2 4 0 - 0 . 2 8 8}$ & $\mathbf{0 . 2 4 1}$ & $\boldsymbol{p}>\mathbf{0 . 9 5}$ \\
\hline
\end{tabular}


necker et al., 2009; Simões et al., 2013). Thus, species can be selected according to their similar functional characteristics and the hydrological period, allowing the coexistence of different species in the environment.

During flooding, the homogenization effect of floods is considered to be a general pattern. Under these conditions, floodplain habitats are connected; as a result, ecological processes and biological communities tend to be more similar (Thomaz et al., 2007). Taken together, our results show that trait convergence could be caused by the homogenization effect of floods, in agreement with our hypothesis.

In an effort to infer assembly rules based on the community composition in a floodplain, a recent study investigated the inter-annual variation in the zooplankton and testate amoeba communities (Lansac-Tôha et al., 2009). This investigation showed that differences between flooding and drought are the most important factors in terms of the structure and dynamics of testate amoeba communities. In addition, the authors also inferred that flooding contributed to species dispersion among the environments. Thus, such conditions result in similar species compositions and, consequently, the functional convergence of traits in testate amoebae.

Moreover, the results also confirmed our hypothesis that trait divergence can occur as a result of drought. Floodplain aquatic habitats are isolated from one another and are subject to local driving forces, such as biotic interactions, during drought (Carvalho et al., 2001). These environmental characteristics can limit the similarity in the traits of co-occurring species (Funk et al., 2008), implicating the occurrence of the functional divergence of traits in aquatic communities.

Numerous studies have shown that environmental isolation during drought promotes alterations in the composition of the testate amoeba community in floodplain lakes (Lansac-Tôha et al., 2008; Costa et al., 2011; Bonecker et al., 2013). The greater the species diversity, the greater the competition for resources (Norberg, 2000), and some species will exclude others that are ecologically similar, leading to the divergence of traits (Katabuchi et al., 2012). Thus, isolated environments could favour trait divergence in testate amoeba communities. There were consistent relationships between the environmental variables and the functional traits of testate amoebae in the different hydrological periods. Different abiotic factors inherent to each hydrological period, such as environmental variables, influence aquatic communities (Neiff, 1996). These factors promote alterations in all the environmental conditions and affect the species according to their functional occupancy (Baranyi et al., 2002). An extensive literature has shown that environmental variability is associated with the structure of planktonic communities in floodplains (Hobaek et al., 2002; Mantovano et al., 2015). Therefore, these variations could also influence the functional traits of testate amoebae.

The results showed that chlorophyll $a$ was positively linked to several functional traits of testate amoebae (A, C, F, and G) in both hydrological periods. The availability of chlorophyll $a$ is one of the major influences on species distributions (Auer et al., 2004). This is because chlorophyll $a$ is directly linked to food resources in aquatic ecosystems (Bastidas-Navarro \& Modenutti, 2007). In support of these results, a recent study reported that a relationship exists between food resources, including chlorophyll $a$, and the functional diversity of testate amoebae, corresponding to environmental filters in the assembly of testate amoeba communities in floodplains (Arrieira et al., 2015b). Thus, chlorophyll $a$ could be inferred to be an important factor in the functional traits of testate amoebae, as shown for the functional traits of Arcellinida, agglutinated, and presence/absence of gas vacuole in this study.

Other environmental variables were related to the functional traits of testate amoebae in the different hydrological periods, as shown for the siliceous shell trait with nitrate, nitrogen, and ammonia and the Euglyphida trait with phosphorus and phosphate. These negative relationships with the phosphorus and nitrogen concentrations indicated a greater influence of nutrients on both functional traits. This could be explained by nutrients potentially limiting both the siliceous shell and Euglyphida traits. For instance, a higher 
phosphorus concentration is one of the environmental factors that restrict the occurrence of some testate amoeba species (Mieczan, 2012). These results are also in agreement with those of Vogt et al. (2013), who demonstrated that phosphorus and nitrogen were the main predictors of zooplankton functional groups. Thus, these environmental variables could also influence the functional traits of testate amoebae.

\section{CONCLUSION}

This study confirmed the influence of hydrological periods on the functional traits of testate amoebae. This temporal factor promoted trait convergence during flooding due to the homogenization effect of floods as well as trait divergence during drought due to environmental isolation, which corroborates the stated hypothesis. The food resources represented by chlorophyll $a$ were an important factor in structuring some functional traits of testate amoebae. Furthermore, nutrients limited other functional groups.

Finally, further studies are needed to contribute to the understanding of the functional role of testate amoebae in structuring aquatic ecosystems, considering their efficiency in responding to environmental variables, especially in floodplain environments.

\section{ACKNOWLEDGMENTS}

The authors thank Bia de Arruda Almeida, MSc., for suggestions and contributions to the statistical analyses. We also thank the Long Term Ecological Research Program (PELD), the National Council of Scientific and Technological Development $(\mathrm{CNPq})$, and the Nucleus of Research in Limnology, Ichthyology and Aquaculture (Nupélia), State University of Maringa (UEM), for logistic and financial support.

\section{REFERENCES}

ALVES, G. M., F. A. LANSAC-TÔHA, E. M. TAKAHASHI \& L. F. M. VELHO. 2008. Fluctuations of Testate Amoebae Populations (Rhizopoda) in Plankton from Different Environments on the Upper Paraná River Floodplain, Brazil. International Review of Hydrobiology, 49: 227-242.

ARRIEIRA, R. L., L. T. F. SCHWIND, C. C. BONECKER \& F. A. LANSAC-TÔHA. 2015a. Use of functional diversity to assess determinant assembly processes of testate amoebae community. Aquatic Ecology, 49: 561-571.

ARRIEIRA, R. L., G. M. ALVES, L. T. F. SCHWIND \& F. A. LANSAC-TÔHA. 2015b. Local factors affecting the testate amoeba community (Protozoa: Arcellinida; Euglyphida) in a Neotropical floodplain. Journal of Limnology, 74: 444-452.

AUER, B, U. ELZER \& H. ARNDT. 2004. Comparison of pelagic food webs in lakes along a trophic gradient and with seasonal aspects: influence of resource and predation. Journal of Plankton Research, 26: 697-709.

BARANYI, C., T. HEIN, C. HOLAREK, S. KECKEIS \& F. SCHIEMER. 2002. Zooplankton biomass and community structure in a Danube River floodplain system: effects of hydrology. Freshwater of Biology, 47: 473-482.

BASTIDAS-NAVARRO, M. \& B. MODENUTTI. 2007. Efecto de la estructuración por macrófitas y por recursos alimentarios en la distribución horizontal de tecamebas y rotíferos en un lago andino patagónico. Revista Chilena de Historia Natural, 80: 345-362.

BEYENS, L. \& R. MEISTERFELD. 2001. Protozoa: Testate amoebae. In: Tracking Environmental Change Using Lake Sediments. 3: Terrestrial, Algal, and Siliceous Indicators. J. P. Smol, H. J. B. Birks \& W. M. Last (ed.): 121-153. Kluwer Academic Publishers: Netherlands.

BONECKER, C. C., A. S. M. AOYAGUI \& R. M. SANTOS. 2009. The impact of impoundment on the rotifer communities in two tropical floodplain environments: interannual pulse variations. Brazilian Journal of Biology, 69: 529-537.

BONECKER, C. C., N. R. SIMÕES, C. V. MINTEVERA, F. A. LANSAC-TÔHA, L. F. M. VELHO \& A. A. AGOSTINHO. 2013. Temporal changes in zooplankton species diversity in response to environmental changes in alluvial valley. Limnologica, 43: 114-121.

BONNET, L. 1975. Types morphologiques, écologie et évolution de la thèque chez les Thécamoebiens. Protistologica, 11: 363-378. 
BORCARD, D., P. LEGENDRE \& P. DRAPEAU. 1992. Partialling out the spatial component of ecological variation. Ecology, 73: 1045-1055.

BORCARD, D., F. GILLET \& L. LEGENDRE. 2011. Numerical Ecology with $R$. Springer, New York.

BOTTRELL, H. H., A. DUNCAN, Z. M. GLIWICZ, E. GRYIEK, A. HEZIG, A. HILLBRICHT-ILKOWSKA, H. KURASAWA, P. LARSSON \& T. WEGLENSKA. 1976. A review of some problems in zooplankton production studies. Norwegian Journal of Zoology, 24: 419-456.

CARVALHO, P., L. M. BINI, S. M. THOMAZ, L. G. OLIVEIRA, B. ROBERTSON, W. L. G. TAVECHIO \& A. J. DARWISCH. 2001. Comparative limnology of South-American lakes and lagoons. Acta Scientiarum. Biological Sciences, 23: 265273.

CAVENDER-BARES, J., A. KEEN \& B. MILES. 2006. Phylogenetic structure of Floridian plant communities depends on taxonomic and spatial scale. Ecology, 87: S109-S122.

COSTA, D. M., G. M. ALVES, L. F. M. VELHO \& F. A. LANSAC-TÔHA. 2011. Species richness of testate amoebae in different environments from the upper Paraná river floodplain (PR/MS). Acta Scientiarum. Biological Sciences, 33: 263-270.

FOURNIER, B., E. MALYSHEVA, Y. MAZEI, M. MORETTI \& E. A. D. MITCHELL. 2012. Toward the use of testate amoeba functional traits as indicator of floodplain restoration success. European Journal of Soil Biology, 49: 85-91.

FUNK, J. L., E. E. CLELAND, K. N. SUDING \& E. S. ZAVALETA. 2008. Restoration through reassembly: Plant traits and invasion resistance. Trends in Ecology \& Evolution, 23: 695-703.

GOLTERMAN, H. L., R. S. CLYMO \& M. A. M. OHNSTAD. 1978. Methods for physical and chemical analysis of freshwaters. Blackwell Scientific Publications, Oxford.

HOBAEK, A., M. MANCA \& T. ANDERSEN. 2002. Factors influencing species richness in lacustrine zooplankton. Acta Oecologica, 23: 155-163.

JUNK, W. J., P. B. BAYLEY \& R. R. SPARKS. 1989. The flood pulse concept in river floodplain systems. In: Proceedings of the International Large River Symposium. D. P. Dodge (ed.): 110-127. Canadian Special Publication of Fisheries and Aquatic Sciences.

KATABUCHI, M., H. KUROKAWA, S. J. DAVIES, S. TAN \& T. NAKASHIZUKA. 2012. Soil re- source availability shapes community trait structure in the species-rich dipterocarp forest. Journal of Ecology, 100: 643-651.

LALIBERTÉ, E. \& P. LEGENDRE. 2010. A distancebased framework for measuring functional diversity from multiple traits. Ecology, 91: 299-305.

LANSAC-TÔHA, F. A., G. M. ALVES, L. F. M. VELHO, B. A. ROBERTSON \& C. Y. JOKO. 2008. Composition and occurrence of testate amoebae in the Curuá-Una Reservoir (State of Pará, Brazil). Acta Limnologica Brasiliensia, 20: 177-195.

LANSAC-TÔHA, F. A., C. C. BONECKER, L. F. M. VELHO, N. R. SIMÕES, J. D. DIAS, G. M. ALVES \& E. M. TAKAHASHI. 2009. Biodiversity of zooplankton communities in the upper Paraná river floodplain: interannual variation from long-term studies. Brazilian Journal of Biology, 69: 539-549.

LANSAC-TÔHA, F. A., L. F. M. VELHO, D. M. COSTA, N. R. SIMÕES \& G. M. ALVES. 2014. Structure of the testate amoebae community in different habitats in a neotropical floodplain. Brazilian Journal of Biology, 74: 181-190.

LEGENDRE, P. \& L. LEGENDRE. 1998. Numerical ecology. Elsevier Science Ltd., Amsterdam.

LEGENDRE, P. \& E. D. GALLAGHER. 2001. Ecologically meaningful transformations for ordination of species data. Oecologia, 129: 271-280.

LUCK, G. W., A. CARTER \& L. SMALLBONE. 2013. Changes in bird functional diversity across multiple land uses: interpretations of functional redundancy depend on functional group identity. Plos One, 8: 1-11.

MACKERETH, F. J. H., J. HERON \& J. F. TALLING. 1978. Water analysis: some revised methods for limnologists. Freshwater Biology, 36: 120.

MANTOVANO, T., R. L. ARRIEIRA, L. T. F. SCHWIND, C. C. BONECKER \& F. A. LANSAC-TÔHA. 2015. Rotifer community structure along a stretch under the influence of dams in the Upper Paraná River floodplain. Acta Scientiarum Biological Sciences, 37: 281-289.

MCGILL, B. J., B. J. ENQUIST, WEIHER, E. \& M. WESTOBY. 2006. Rebuilding community ecology from functional traits. Trends in Ecology \& Evolution, 21: 178-185.

MEISTERFELD, R. 2002. Testate amoebae with filopodia. In: The illustrated guide to the protozoa. J. J. Lee, G. F. Leedale \& P. Bradbury (ed.). Society of Protozoologists, Lawrence. 
MENDEZ, V., J. A. GILL, N. H. K. BURTON, G. E. AUSTIN, O. L. PETCHEY \& R. G. DAVIES. 2012. Functional diversity across space and time: trends in wader communities on British estuaries. Diversity and Distribution, 18: 356-365.

MIECZAN, T. 2012. Distribution of testate amoebae and ciliates in different types of peatlands and their contributions to the nutrient supply. Zoological Studies, 51: 18-26.

NEIFF, J. J. 1996. Large rivers of South America: toward the new approach. Verhandlungen des Internationalen Verein Limnologie, 26: 167-180.

NIKOLAEV, S. I., E. A. D., MITCHELL, N. B. PETROV, J. FAHRNI \& J. PAWLOWSKI. 2005. The testate lobose amoebae (Order Arcellinida Kent, 1880) finally find their home within Amoebozoa. Protist, 156: 156-191.

NORBERG, J. 2000. Resource-niche complementarity and autotrophic compensation determines ecosystem-level responses to increased cladoceran species richness. Oecologia, 122: 264-272.

OGDEN, C. G. 1991. Gas vacuoles and flotation in the testate amoeba Arcella discoides. The Journal of Protozoology, 38: 269-270.

OKSANEN, J., F. G. BLANCHET \& R. KINDT. 2011. Vegan: Community Ecology Package. R package version 2.0-6. Available from: http://vegan. r-forge.r-project.org/.

PETCHEY, O. L. \& K. J. GASTON. 2006. Functional diversity: back to basics and looking forward. Ecology Letters, 9: 741-758.

PILLAR, V., L. DUARTE, E. SOSINSKI \& F. JONER. 2009. Discriminating trait-convergence and trait-divergence assembly patterns in ecological community gradients. Journal of Vegetation Science, 20: 334-348.

R CORE TEAM. 2013. $R$ : A language and environment for statistical computing. R Foundation for Statistical Computing, Vienna. Available from: http://www.R-project.org.

ROBERTO, M. C., N. F. SANTANA \& S. M. THO-
MAZ. 2009. Limnology in the Upper Paraná River floodplain: large-scale spatial and temporal patterns, and the influence of reservoirs. Brazilian Journal of Biology, 69: 717-725.

SCHWIND, L. T. F., R. L. ARRIEIRA, J. D. DIAS, N. R. SIMÕES, C. C. BONECKER \& F. A. LANSACTÔHA. 2016. The structure of planktonic communities of testate amoebae (Arcellinida and Euglyphida) in three environments of the Upper Paraná River basin, Brazil. Journal of Limnology, 75: 78-89.

SIMÕES, N. R., J. D. DIAS, C. M. LEAL, M. B. L. SOUZA, F. A. LANSAC-TÔHA \& C. C. BONECKER. 2013. Floods control the influence of environmental gradients on the diversity of zooplankton communities in a neotropical floodplain. Aquatic Sciences, 75: 607-617.

THOMAZ, S. M., L. M. BINI \& R. L. BOZELLI. 2007. Floods increase similarity among aquatic habitats in river-floodplain systems. Hydrobiology, 579: 1-13.

VELHO, L. F. M., F. A. LANSAC-TÔHA \& L. M. BINI. 2003. Influence of environmental heterogeneity on the structure of testate amoebae (Protozoa, Rhizopoda) assemblages in the plankton of the upper Paraná river floodplain, Brazil. International Review of Hydrobiology, 88: 154-166.

VIOLLE, C., M. L. NAVAS, D. VILE, E. KAZAKOU, C. FORTUNEL, I. HUMMEL \& E. GARNIER. 2007. Let the concept of trait be functional! Oikos, 116: 882-892.

VOGT, R. J., B. E. BEISNER \& Y. T. PRAIRIE. 2010. Functional diversity is positively associated with biomass for lake diatoms. Freshwater Biology, 55: 1636-1646.

VOGT, R. J., P. R. PERES-NETO \& B. E. BEISNER. 2013. Using functional traits to investigate the determinants of crustacean zooplankton community structure. Oikos, 122: 1700-1709.

WEIHER, E. \& P. A. KEDDY. 1999. Ecological assembly rules: perspectives, advances and retreats. Cambridge University Press, Cambridge. 